\title{
Rola bola: dispositivo que produz guetos culturais
}

http://dx.doi.org/10.11606/1807-5509202000040623

Gabriel da Costa Spolaor* Mario Luiz Ferrari Nunes*

\section{*Departamento de Educação Física \\ e Humanidades, Universidade Estadual \\ de Campinas. \\ Campinas, SP, Brasil.}

\begin{abstract}
Resumo
Dentre as diversas práticas pedagógicas produzidas no currículo da Educação Física escolar, investigamos a popularmente denominada rola bola. Inferimos seus efeitos em uma turma de $2^{\circ}$ ano do Ensino Médio de uma escola da rede estadual de São Paulo. Por meio de uma etnografia, realizamos observações sistematizadas, registradas em diário de campo para a produção de dados. Para a interpretação dos resultados, tomamos as noções de identidade e diferença produzidas no campo dos Estudos Culturais, em sua vertente pósestruturalista. Notamos a presença de guetos culturais instituídos no transcorrer das aulas, nos quais se evidenciam fronteiras simbólicas que delimitam formas de pertencimento dos sujeitos, bem como as condições de possibilidades de negociações promovidas pelas relações e práticas sociais que emanam no interior das aulas.
\end{abstract}

Palavras-Chave: Educação Física; Ensino Médio; Currículo; Identidade; Diferença.

\section{Introdução}

Desde a promulgação da LDB 9394/96, o debate educacional intensificou-se em torno das reformas curriculares produzidas em diferentes níveis de ensino. A razão central é a de que o currículo está associado às formas de controle e regulação social. As diversas políticas curriculares produzidas visam a produção da identidade ideal que deverá compor a sociedade brasileira, a fim de garantir a inserção do país na ordem econômica global.

Como componente curricular da educaçáo básica, a Educação Física (EF) também não escapa desse jogo. A partir da década de 1980, no Brasil, o debate na área fez emergir três concepções diferentes no tocante ao seu objeto de conhecimento: a atividade física, o movimento humano e a cultura corporal ${ }^{1}$. O que se vê, desde então, são várias produçôes que versam sobre as especificidades, objetivos, conteúdos e práticas pedagógicas para o componente no contexto escolar. A ebulição dessas produçóes aproximou a EF dos estudos produzidos no campo do currículo, suscitando classificaçôes ${ }^{2}$ e análises a respeito das identidades que cada proposta curricular visa constituir ${ }^{3}$.

Atualmente, esse debate sobre a especificidade da área e as teorias do currículo ainda permanece em efervescência, principalmente em função de medidas tomadas recentemente pelo governo federal como, a criação da Base Nacional Comum Curricular (BNCC) e a reforma do Ensino Médio, instaurada por meio de Medida Provisória (MP 746/2016) e sancionada em Fevereiro de 2017.

Em que pese a larga produção acadêmica, editorial e de políticas curriculares que fomentam programas de Educação Física para a escola, no contexto da prática outras possibilidades didático-metodológicas são engendradas pelos docentes. Dentre as diversas práticas pedagógicas pensadas e construídas na Educação Física escolar, nesta pesquisa investigamos a dinâmica cultural e social produzida pela popularmente denominada rola bola. Esse é um termo bastante conhecido, que, em geral, é utilizado para nomear as aulas em que os professores ofertam vários materiais para os alunos como aparelho de som, bolas, cordas, etc., delegando 
a eles tanto a resolução da distribuição do espaço como qual será a dinâmica da aula.

Alguns trabalhos ${ }^{4,5}$ criticam essa prática, em virtude da falta de reflexão por parte dos docentes a respeito dos conhecimentos que nela deveriam ser abordados, dos objetivos a serem alcançados, assim como dos modos de seleção e organização das atividades de ensino e finalidades da avaliação. Ressaltam, sobretudo, a função social do professor nos processos pedagógicos, caracterizando o ato de rolar a bola, como um desinvestimento e, até mesmo, uma forma de abandono docente. Mesmo diante das críticas, do intenso debate a respeito do currículo e da ampla divulgação de variados métodos de ensino, esse modelo de aula, que não aparecem nenhum curso de formação de professores, ocorre com frequência no contexto escolar.

Concordamos com as críticas a respeito da ausência de sistematização desse tipo de aula e da diferenciação das proposiçóes comumente apresentadas pelos currículos de Educação Física como, esportivista, psicomotor, desenvolvimentista, saúde renovada, críticos ou cultural $^{2}$. A essas, acrescentamos algo mais: cremos que seria errôneo e ingênuo dizer que na aula rola bola nada acontece ou que não ocorram aprendizagens. Pelo contrário, a vida social construída nas relações de diálogo, tensão e disputa entre os alunos, assim como entre eles e a docência, dinamizam constantemente a trama cultural e faz com que as aulas se tornem contextos potentes de investigação a respeito tanto da cultura corporal e escolar ali apresentada e constantemente produzida, como, também, das formas de regulação que produzem representaçóes e marcam identidades e diferenças.

Perante nossa posição, optamos por ir além da discussão centrada na atuação docente e da relação desta com a prática pedagógica sistematizada ou não. Inserimos nossas análises nos debates a respeito da inter-relação currículo, cultura e identidade. Tratamos o rola bola como dispositivo de regulaçáo da conduta de seus sujeitos, como política de subjetividade que produz discursos a respeito do que é a Educação Física escolar e de quem são e podem ser seus sujeitos em face das condiçôes que se instauram. Cabe aqui a explicação detalhada acerca da noção de dispositivo descrita por Foucault (p. 244) ${ }^{6}$ ora utilizada:

\section{Método}

A fim de analisar as relaçōes sociais, simbólicas, valores e disputas presentes nas aulas, nos pautamos
Através deste termo tento demarcar, em primeiro lugar, um conjunto decididamente heterogêneo que engloba discursos, instituiçôes, organizaçốes arquitetônicas, decisões regulamentares, leis, medidas administrativas, enunciados científicos, proposiçôes filosóficas, morais, filantrópicas. Em suma, o dito e o não dito são os elementos do dispositivo. O dispositivo é a rede que se pode estabelecer entre estes elementos. Em segundo lugar, gostaria de demarcar a natureza da relaçáo que pode existir entre estes elementos heterogêneos. Sendo assim, tal discurso pode aparecer como programa de uma instituição ou, ao contrário, como elemento que permite justificar e mascarar uma prática que permanece muda; pode ainda funcionar como reinterpretação desta prática, dando-lhe acesso a um novo campo de racionalidade. Em suma, entre estes elementos, discursivos ou não, existe um tipo de jogo, ou seja, mudanças de posição, modificaçôes de funçôes, que também podem ser muito diferentes. Em terceiro lugar, entendo dispositivo como um tipo de formaçấo que, em um determinado momento histórico, teve como funçẫo principal responder a uma urgência. $\mathrm{O}$ dispositivo tem, portanto, uma função estratégica dominante.

O rola bola, enquanto dispositivo, enreda subjetividades em uma trama que classifica e fixa os sujeitos em representaçóes que se fecham no que aqui denominamos guetos ${ }^{a}$ culturais. Está saturado de conhecimentos e verdades sustentadas e reforçadas por práticas que apoiam a hegemonia de certos saberes em detrimento de outros. É marcado por relaçóes de poder específicas, produz saberes, faz circular valores, governa as condutas dos alunos, favorece modos de ser e constitui identidades. Dito isso, nos perguntamos: como as relações sociais entre os alunos e entre eles e a(o) docente responsável são produzidas? Quais seus efeitos para a produção da identidade e marcação da diferença? Como os mecanismos de identificação entre os sujeitos são articulados? Como se dá o processo de regulação da cultura estabelecida nessas aulas? O que se produz e reproduz no rola bola?

Diante dessa condição, ao investigar sua dinâmica, esperamos contribuir com a produção acadêmica a fim de instigar novas reflexóes.

no trabalho de $\mathrm{MAIA}^{7}$, em relação à pesquisa de cunho etnográfico. No presente estudo, a partir 
de observaçốes com uso de diário de campo como forma de registro e produçáo de dados, acompanhamos por três meses as aulas de Educaçáo Física escolar de uma turma de $2^{\circ}$ ano do Ensino Médio de uma escola da rede estadual paulista. A escola situa-se na regiáo central de uma cidade do interior de São Paulo, é de pequeno porte e atende 10 turmas, todas do Ensino Médio. É constituída por aproximadamente 300 estudantes, com média de 30 alunos por turma. A maioria pertence a classe socioeconômica baixa e mora em bairros periféricos da cidade.

A docente responsável pela turma observada vincula-se à categoria $\mathrm{O}^{\mathrm{b}}$. À época da observação, realizava substituiçấo de uma colega. Atua há cerca de 10 anos na rede, além de trabalhar em um clube como instrutora de musculação. Cursou Educação Física em uma Instituição de Ensino Superior particular, com o intuito de ser técnica esportiva.

Dentre as justificativas para as aulas denominadas por ela mesma de "rola bola", destaca: (1) as condiçôes materiais e físicas oferecidas pelo estado e pela escola, que não permitem a realização de boas aulas de Educação Física. De acordo com a sua concepção de EF, boas aulas propiciam a prática de modalidades esportivas e atividades físicas, a fim de possibilitar a qualidade de vida e a melhora da saúde dos alunos. Destacamos aqui, a falta de coerência entre a concepção de área que apresenta e o discurso veiculado pelo Currículo do Estado de São Pauloc; (2) por ser categoria $\mathrm{O}$ e iniciado a substituição das turmas com o período letivo em andamento, a professora não se sentiu legitimada para ministrar as aulas. Mesmo sabendo que as turmas seriam de sua responsabilidade até o final do ano letivo, no seu entender essa condição fez com que ela não se considerasse como a professora efetiva; (3) a falta de legitimidade gerou diversas resistências por parte dos alunos. Com isso, não tentou modificar o que eles já faziam desde o começo do ano, o que denota que naquela escola o rola bola é uma pedagogia instituída. Para ela, as aulas tinham uma dinâmica própria que a impedia problematizar e desconstruir o que acontecia, restava apenas, deixar rolar a bola. Apesar de não focarmos nossa atenção na identidade docente, não é demais realçar que a posição de sujeito desta professora reforça a ordem discursiva dominante, que enuncia o professor de escola pública como impotente para enfrentar os problemas que imperam nas escolas. Não à toa, o seu enunciado é corriqueiro na ordem do discurso da docência.

A partir deste contexto, inferimos os efeitos desta prática pedagógica na produção da identidade cultural tanto do componente Educação Física como na dos alunos. Para tanto, ancoramos nossa investigação no campo dos Estudos Culturais, em sua vertente pós-estruturalista.

\section{Mapa teórico}

Encontramos nos Estudos Culturais ${ }^{8}$ ampla discussão sobre a constituição das identidades e diferenças. Ao contrário da compreensão de que a identidade produz a diferença, nesse campo de estudo, torna-se necessário tratar a identidade como o produto da relação entre diferenças. Isso é importante de ser mencionado, uma vez que, no primeiro modo de olhar para a cultura, as identidades das coisas do mundo e dos grupos culturais, bem como seus representantes, já estão fixadas como algo estático e dado. No entanto, isso não é natural. Decorre das lutas pelo domínio do processo de significação. $\mathrm{Ou}$ seja, o que está em jogo é a afirmaçáo das formas de ver o mundo, os modos de validar os significados das coisas e tomá-los como verdade. Feito isso, torna-se necessário garantir a estabilidade da cultura e afastar qualquer ameaça à ordem social. Para tanto, normalmente, tomamos a identidade como referência e a diferença como negação ou oposição do estabelecido, logo, como algo que tem que ser marcado para ser combatido. Cabe reforçar que a noção de diferença escapa a qualquer tentativa de leitura binária entre o que é o Mesmo e o que é o Outro. A diferença, por estar sempre em processo não possui uma origem nem um destino final.

A noção de identidade e diferença aqui apresentada entende que ambas são decorrentes de atos de diferenciação linguístico. São produções da linguagem, que estruturaram e permitem a comunicação entre as pessoas. É por meio da linguagem que os significados dos signos governam as açôes de quaisquer grupos culturais. Afinal, precisamos da linguagem para dar sentido as coisas do mundo. Se os sentidos das coisas do mundo são produçóes da linguagem, isso significa afirmar que as coisas não estão dadas e cabe ao ser humano, na relação com o outro, com a cultura, a sua invenção e nomeação. Dizer que são criaçôes implica dizer que são frutos dos processos de produção simbólica, atravessadas por relaçóes de poder e que têm nas práticas discursivas seu veículo de comunicação.

Como fruto da linguagem, o processo de produção da identidade e da diferença não acontece de forma tranquila. Ela depende das relaçóes sociais entre os sujeitos no interior de cada cultura e no encontro 
entre elas. Para BaKhtin ${ }^{9}$, cada ato enunciativo é um elo único de uma cadeia criativa e dialógica infinita. O sujeito, sempre em resposta ao outro (tido como a diferença), se posiciona em um determinado lugar, estabelece relaçôes dialógicas com signos que identificam grupos, sujeitos, enunciados e práticas culturais que sustentam seu posicionamento; direciona sua expressão para um interlocutor, utiliza-se de um gênero discursivo permitido no contexto, escolhe as palavras, a composição, o estilo e entonação do enunciado. Esse movimento de acabamento provisório, produz sentidos singulares e irrepetíveis para o enunciado. No momento da expressão, o sujeito torna-se, por sua vez, o outro do outro, a diferença para o outro, dando continuidade ao encadeamento enunciativo.

Nessa dinâmica, os signos tornam-se arenas de luta entre os grupos culturais, pois, ao mesmo tempo em que afirmam o que venha a ser a realidade para aqueles que os produziram, reforçando determinado significado na sua utilização, encontra-se também um efeito de refração, atualização, apagamento, estabilização deste significado a partir de sentidos singulares atribuídos pelos sujeitos. Esse movimento de reflexão e refração ${ }^{10}$ permite que o significado das coisas do mundo seja sempre provisório, inacabado. Possibilita que a cultura continue em movimento, em dinâmica constante na produçáo de sentidos mediante processos de significação. Cabe assim dizer que a cultura é um campo de disputa pelo controle dos significados e, por conseguinte, pelo acesso privilegiado aos bens sociais ${ }^{8}$.

Para FouCAUlT ${ }^{6}$, o discurso não é apenas um jeito para descrever as coisas. Para ele, o discurso fabrica as coisas. $\mathrm{O}$ autor reforça que o discurso é um conjunto de enunciados que produz as formas de vermos e nomearmos o que vemos, determina o que pode ser dito e aquilo que não deve ser dito, quem está autorizado a dizer e quem não está. Destarte, o discurso produz efeitos no sujeito mediante relaçôes de poder.

Como a noção de identidade traz consigo um aspecto essencialista, autores como $\mathrm{HALL}^{11}$ adotam o conceito de "identificação", pois este termo pode funcionar ora como afirmação, ora como imposição de identidade. Para o autor, a identificação é um processo contingente de articulação entre sujeitos ou grupos, cujos discursos utilizados causam efeitos de fronteira ou definem o limite entre o eu e o outro. A identificação é o que permite aos indivíduos assumirem determinadas posiçóes nos discursos, no interior de determinados sistemas simbólicos e se assumirem e se reconhecerem enquanto membros de um grupo, porém nunca de forma completa ou definitiva. Desse modo, torna-se necessário afirmar quem é quem, quem pertence ou não a determinado grupo cultural. A construção da identidade e da diferença depende do modo como as sociedades produzem suas classificaçôes. Quem exerce e controla o poder de classificar tem o privilégio de atribuir valores e hierarquizar as coisas classificadas e expurgar para as margens e de lá manter sob seu controle aqueles que não pertencem à ordem normatizada, marcando assim a diferença.

Sendo fruto da linguagem, nesse jogo, a diferença é vista como perturbação da norma, como ameaça a qualquer tentativa de determinar a identidade das coisas. Logo, ela tem que ser produzida para localizar o perigo que manifesta, classificada para ser identificada, marcada para ser assimilada, domesticada ou afastada, marginalizada. Determinar quem é a norma (a identidade) e quem é a diferença (o outro) é o que está em jogo nas relaçôes de poder ${ }^{8}$.

A legitimidade da identidade e a negação da diferença estão ligadas diretamente ao modo pelo qual elas são representadas, isto é, ao modo como as práticas de significação e os sistemas simbólicos atribuem significado ao que as pessoas são, fazem, produzem. A noção de representação aqui adotada não é um meio de comunicaçáo, tampouco aloja em si o real ou o significado verdadeiro. Ao adotarmos a noção de representação na perspectiva dos Estudos Culturais, estamos a afirmar que ela é expressa em uma dimensão de significante. Ela é uma forma de atribuir sentido e dependente da linguagem que a produz e, por conseguinte, traz consigo toda instabilidade que caracteriza a linguagem. Ela diz respeito ao modo como a realidade é representada, logo também está ligada às relaçôes de poder que determinam os significados dos sistemas simbólicos e as formas como os sujeitos se representam e são representados ${ }^{12}$.

WoODWARD ${ }^{13}$ explana que a construção simbólica da identidade decorre do modo como as formas de afiliação dos grupos de pertencimento são marcadas pelo uso de certos artefatos ou aspectos materiais e rituais como, por exemplo: preferências por roupas, revistas, músicas, práticas corporais; formas de cuidar do corpo; gestualidades; fatores biológicos como cor da pele, tamanho, idade; formas de se movimentar; comportamentos morais; cultos religiosos que frequentam; opçóes quanto à afetividade etc.. Esses símbolos, ao mesmo tempo que criam a noção de pertencimento, produzem a diferença porque é por meio da sua expulsão que se estabelecem as fronteiras simbólicas que anunciam quem está autorizado a 
entrar e quem não está. A identidade, ao ser marcada por recursos materiais, gera efeitos sobre os artefatos e, por conseguinte, sobre a produção de bens e a representação A depender do jogo pelo controle da significação, a exclusão produzida é mais ou menos sentida. São esses fatores que promovem as desvantagens econômicas, políticas e sociais.

Diante das complexas condiçóes sociopolíticas em que vivemos, esse aporte teórico aproximou os Estudos Culturais das questóes emergentes do campo do currículo. O que se nota é que essa aproximação potencializou outros olhares para os estudos do currículo por meio de estudos que expandem a noção de currículo para outras práticas culturais, os que investigam políticas e programas governamentais, e aqueles que trabalham com o conceito de identidade e diferença a fim de interrogar quem o currículo almeja produzir ${ }^{14}$, no qual nos situamos.

O debate atual sobre os processos de escolarização questiona como os discursos presentes no currículo fazem circular e manter significados hegemônicos, para assim promover e tentar perpetuar as relaçóes assimétricas de poder e delimitar as fronteiras simbólicas entre grupos. O currículo também é uma forma de luta pelo controle do que se transmite e se ensina para garantir para certos grupos sociais o controle social dos processos de significação, do que seja a realidade, a verdade das coisas e a do sujeito.

No campo da Educação Física isso também ocorre e, talvez, de forma mais visível ${ }^{15}$. Afinal o corpo está constantemente exposto aos sistemas classificatórios que determinam quem é o habilidoso, quem não é, quem se afilia a prática corporal valorizada, quem simpatiza com sujeitos e gestos das práticas corporais renegadas, quem não quer participar, quem é adepto a um estilo de vida ativo e consumista e quem a ele resiste. Aspectos que requerem maiores cuidados quanto aos efeitos da sua prática, principalmente quando a escola e seus agentes optam em deixar essa questão à mercê dos acontecimentos (idem).

Autores como McLAREN ${ }^{16}$ e Giroux ${ }^{17}$ asseveram que há de se considerar a linguagem mediante os fatores que determinam o dia a dia dos alunos no interior das práticas sociais que a escola promove. É nesse jogo, que o currículo produz açóes que permitem aos seus sujeitos elaborarem saberes, valores, e representaçóes a respeito das coisas do mundo e das diversas identidades que por ele (currículo) são apresentadas. Se a linguagem não é apenas uma forma de narrar e decifrar a realidade, mas constitui as práticas e as identidades sociais ${ }^{18}$, investigar o que acontece na sala de aula, as práticas e os discursos que nela se produzem e reverberam, permitem-nos analisar possíveis formas de produção e afirmaçáo de identidades e, por conseguinte, formas de marcação e exclusão da diferença.

Com a realização das observaçóes, notamos que a dinâmica da aula rola bola favoreceu a produção de cinco grupos culturais distintos. Estes apresentaram certa regularidade de encontro e manifestação de seus fazeres no contexto estudado. Em comum estavam as práticas de fronteira entre os que podem ou não pertencer a eles, representados por alguns marcadores simbólicos, constituindo os guetos culturais.

A seguir, apresentamos uma possível interpretação para esse acontecimento. Enfatizamos cada um dos guetos, sem a pretensão de imobilizá-los e fixá-los de forma abstrata fora da dinâmica social, pelo contrário. Chamamos a atenção para como somente na vida social, na relação entre diferenças, as identidades são produzidas. Mostraremos também como em diferentes situaçóes observadas, as fronteiras simbólicas dos guetos são abertas, borradas, o que indica que elas podem ser redinamizadas e remodeladas.

Destacamos que a ordem escolhida para apresentar os guetos construiu-se a partir da interpretação feita a respeito da hierarquização produzida nas aulas. Identificamos que essa diferenciação quanto a significação e valorização dos grupos tem a ver com as concepçóes de Educação Física presente nas aulas, ligada à prática de atividade física/esporte, da idealização de alunos ativos e participativos nesse contexto. Todas essas condiçóes são atravessadas por marcadores identitários de gênero, etnia, classe, geração, domínio cognitivo e o de habilidade motora.

\section{Resultados e Discussão}

Gueto 1

O primeiro gueto é formado apenas por meninos que jogam futebol. Apesar de ser um grupo pequeno, com poucos integrantes, consideramos que ele seja o que mais se aproxima da identidade de aluno legitimada/ desejada no contexto da EF. Nesse sentido, ao passo que é colocado como identidade dos participantes da 
aula do componente, afasta para as margens da quadra os demais grupos que não compartilham dos mesmos gostos, pensamentos, atitudes, valores, gênero, marcadores culturais, enfim, o que atrapalha: a diferença.

Eles são os primeiros a descer para a quadra e logo que a professora aparece iniciam-se os chamados, geralmente em tom de imposição: "Dona!! Rápido, rápido... busca a bola lá! Vai!". Na maioria das vezes, a professora não fala nada. Expressa concordância com o pedido dos garotos e busca as bolas na sala de materiais.

Enquanto as bolas não chegavam, os garotos, já no meio da quadra, tiravam seus tênis, em sua maioria da marca Nike e Oakley, colocando-os perto das mochilas na arquibancada. Também tiravam as camisetas, dobradas e colocadas perto do material. Segundo eles, jogar descalço é melhor para o controle da bola como, também, para não estragar a sola dos tênis. Em relação às camisetas, ficar sujo e suado "pega mal", visto que, sem elas, além de resolverem o problema da higiene pessoal, possibilita impressionar e aparecer para as meninas. Assim, exceto em dias de chuva, o "uniforme" de jogo do grupo eram os pés descalços, uma bermuda larga de surfista e peito aberto, sem camiseta.

Quando a professora volta com a bola, à distância ela joga para eles e grita: "Não é para dar perdido na minha bola, hein? Se não, ninguém joga mais!". $\mathrm{O}$ ato de rolar a bola para eles, bola essa que é considerada como "dela", mais do que um movimento de entrega, tão naturalizado nas aulas de Educação Física, carrega, simbolicamente, a legitimação do gueto que controla não só o espaço da quadra enquanto fronteira, como fazem dessa zona de contato a forma com que os demais alunos devem se sujeitar para participar da aula e do jogo.

Eles pegam a bola e começam a fazer embaixadinhas, chutam ao gol, comemoram, imitando gestos de jogadores famosos como, por exemplo, o salto e gancho no ar do Neymar e a pose, com peito estufado, de Cristiano Ronaldo. Observamos que as imitaçôes dos jogadores dos times europeus mais ricos não cessam apenas nos gestos de comemoraçáo. Se estendem para o jeito de correr, de andar, empregar várias gírias da "malandragem", bem conhecida na cultura do futebolista brasileiro.

As representaçôes de sujeito juvenil e masculino se reforçam. Se não bastassem as marcas dos tênis e os cuidados com as camisetas, há grande preocupação com os cabelos, arrumados com gel e luzes, assim como com o modo que os mesmos são constantemente ajeitados ao longo da peleja. Além de aspectos generificados, que exaltam determinado modo de ser jovem e masculino, esses marcadores mostram a relação desse gueto com a mídia e o mercado esportivo. Indicam que o que acontece nas aulas de Educaçáo Física não está desvinculado do que ocorre na cultura promovida pelas mídias. Muito pelo contrário, é mais um contexto onde a cultura marcada por hierarquias, valores e poder se manifesta de forma dinâmica.

As aulas que acompanhamos eram duplas e apesar de a professora liberar a bola de futebol para este gueto, logo no início, o seu acesso à quadra era restringido por outro gueto (será apresentado na sequência) também constituído apenas por meninos, mas em maior quantidade. No entanto, esses jogavam, principalmente, basquete. Devido as várias discussōes que aconteceram no começo do ano, ficou combinado entre os grupos que na primeira aula a quadra seria do basquete e na segunda aula, apenas o futebol seria permitido. Nessas negociaçóes dos espaços, as meninas são invisibilizadas, reforçando os estudos de $\mathrm{VAGO}^{19}$, AltMan $^{20}$, Wenetz ${ }^{21}$ e outros.

Algo que nos chamou atenção nesse acordo, reforçando o que dissemos sobre o privilégio do gueto 1 , é que mesmo o futebol não sendo permitido na primeira aula, em nenhum momento ele não é jogado. Enquanto o gueto do basquete escolhia os times, o gueto do futebol jogava do outro lado da quadra. Quando o basquete iniciava, ora jogavam nas laterais, trocando passes, fazendo embaixadinhas, ora invadiam o espaço oposto em relação ao que estava ocorrendo $\mathrm{o}$ ataque no basquete. Por fim, quando o futebol era permitido, o gueto do basquete era convidado para jogar contra os meninos do futebol.

Situação interessante de observar. Além da competição pelos pontos do jogo, claramente era uma disputa simbólica pela identidade e legitimidade cultural dos grupos naquele contexto. Apesar de todos jogarem juntos, nas partidas, inicialmente, os guetos não se misturavam. Afinal, a ginga, modo de correr, driblar com a bola nos pés expressa pelos meninos do futebol, delimitavam quem era quem. Os meninos do basquete, por náo conseguir acompanhar esse tipo de movimentação, sempre perdiam as contendas.

Percebendo essa dificuldade, para poder "dar jogo", na segunda partida, geralmente, os times se misturavam. Como resultado, as fronteiras apenas mudavam de forma. O controle do jogo permanecia nos pés dos garotos do futebol. Agora, os meninos do basquete pouco tocavam na bola. Como afirmou NunEs ${ }^{15}$, nas práticas esportivas escolares misturar os times é mais do que atender exigências impostas pela escola. Trata-se de uma condiçáo para se enaltecer a identidade desejada - os habilidosos, e marcar a diferença - o inábil e, com 
isso, reforçar a superioridade de quem tolera. No caso em tela, mesmo sendo proposta por eles, a mescla não foi condição para romper as fronteiras entre os guetos. A abertura se dá como forma de negociação do espaçotempo das aulas.

Outro aspecto merece realce. As teorias críticas de currículo nos ensinaram que o currículo pode ser significado como aquilo que os estudantes têm oportunidade de aprender, assim como, aquilo que eles não têm oportunidade de aprender. Apesar de ser uma definição que inclui tudo, percebemos que essa definição destaca os critérios de seleção de um objeto de estudo e o modo como ele é apresentado, assim como a omissão dos critérios da exclusão de outros. É desnecessário abordar aqui tanto a hegemonia do futebol na Educação Física escolar brasileira, como as questóes de gênero que esse debate engendrou. No entanto, cabe reforçar que a opção do rola bola contribui para que os sujeitos do gueto 1 fixem e estabilizem significados. $\mathrm{O}$ que o rola bola fortalece são os modos de unificar a identidade dos sujeitos desse gueto, enquanto representação dominante de ser jovem, do gênero masculino e articulá-la à determinada prática corporal, aos produtos que consomem e às formas de regulação da conduta de seus membros.

\section{Gueto 2}

Diferentemente dos garotos do futebol, no início da aula, os garotos do basquete entravam em quadra e em roda, conversavam à espera da professora trazer a bola. Quando percebiam a demora, corriam para a sala de material a fim de buscá-la por conta. Percebe-se também uma ação diferente permeando a relação, o que indica outra representação docente em cena. Além das conversas, frequentemente saltavam na direção da tabela de basquete na tentativa de tocar ou puxar o aro e a redinha. Segundo eles, essa brincadeira era um teste. Avaliavam ao longo das semanas a impulsão, a fim de aumentar a possibilidade da enterrada. Para nós tratava-se de códigos que compóem um ritual de afirmação e pertencimento.

Esse gueto era formado por cerca de 10 garotos e, mais uma vez, sem a presença de meninas. Metade deles era mais alta do que todos os membros da sala. Havia também meninos mais baixos no grupo. Apesar das diferenças físicas, eram adeptos do esporte em virtude das transmissóes televisivas e online dos jogos da liga estadunidense (NBA) e, por conseguinte, criaram laços de afiliação. Como qualquer grupo identitário busca criar seus traços comuns, nesse grupo, além da audiência aos jogos, comentários sobre os ídolos do basquete, alguns garotos desse gueto mostravam interesse por camisetas, bermudas e calçados dos times e jogadores da liga citada. No lugar do uniforme da escola, nas aulas de Educação Física iam com regatas e bermudas dos times, que diferentemente dos garotos do futebol, eram maiores e mais largas. Quanto aos tênis, a preferência era pelos de cano alto das marcas Adidas e Nike, reforçando aspectos relativos ao consumo como forma de identificação.

Percebe-se que o valor dos objetos não estão neles em si. Como indica CANCLINI ${ }^{22}$, o valor mercantil de qualquer artefato cultural não decorre do custo em si. Ele advém das forças que produzem interações nas quais os grupos culturais se engendram. Ou seja, os significados que carregam e o modo como são distribuídos entre os membros do grupo são os elementos que marcam os membros do gueto. A aquisição do artefato se dá pela importância e significado social para o grupo ao qual o sujeito pertence e define tanto a sua posição como a função a desempenhar.

Essas informaçóes reforçam dois aspectos. O primeiro, como já assinalado por renomados intelectuais, refere-se à força das mídias na construção dos modos de pertencimento e, neste caso, dos guetos. O segundo, no tocante ao fato que os múltiplos processos de identificação que existem na cultura são potentes para o borramento de fronteiras e a consequente aproximação entre alunos muitas vezes vistos como "os de fora".

Os times eram escolhidos por meio de arremessos de lance livre. Cada um que acertava, ia para um time diferente. $\mathrm{O}$ que indica outra concepção de jogo em relação ao gueto $1 \mathrm{e}$, porque não dizer, outras configuraçôes das relaçôes de poder. Com o início do jogo, eles mostravam algum conhecimento de regras, mas pouco domínio em relação aos aspectos técnicos e táticos. Observamos que nas jogadas de ataque os garotos pouco passavam a bola. Optavam por resoluções rápidas por meio de jogadas individuais, geralmente imitando algumas que foram transmitidas ao longo da semana pela mídia como, por exemplo, os crossovers e inúmeros arremessos de 3 pontos, na tentativa de se aproximar do modelo de jogo de Stephen Curry e Klay Thompson, atletas do Golden State Warriors, considerado por eles o melhor time da liga estadunidense.

$\mathrm{Na}$ defesa, os garotos tinham poucas referências e não sabiam muito bem diferenciar estratégias. Eles apenas acompanhavam os adversários. Por outro lado, tentavam várias vezes bloquear os arremessos dos adversários, jogada conhecida por "toco". Como esse tipo de jogada pouco dava certo, muitas vezes cometiam 
faltas. Apesar das várias tentativas sem sucesso, quando o "toco" acontecia, o jogo parava, porque tanto os jogadores da defesa, quanto os do ataque gritavam e comemoravam o lance. Sem dúvida, essas práticas não discursivas criam formas de pertencimento, afirmam um jeito de jogar e reforça traços de masculinidade.

Chamamos atenção para esses lances, para demonstrar como os valores destacados pelas mídias e propagandas da liga estadunidense impactam e marcam os modos de jogo desses garotos e produzem identidades e diferenças. Por um lado, pode-se dizer que esse conjunto de valores e significados, que eram manifestados e elaborados de forma dinâmica ao longo das aulas rola bola, contribuía para a constituição daquele gueto, por outro, quem não dominava aqueles códigos, não participava do grupo e do jogo.

"A gente não joga por vários motivos, primeiro que a gente não conhece as regras e não sabe nem bater uma bola. Segundo, que não sabemos o nome dos times, além de não ter paciência de ver aqueles jogos que demoram tanto tempo." (Comentário de um aluno do gueto 1 )

Interessante notar que, de um lado, por não ter tanta divulgação midiática naquele contexto, a prática do basquete cria uma modalidade de fronteira para além do consumo de artefatos. Ela é da ordem da partilha de códigos de comunicação, que cria uma comunidade específica. Por outro, o futebol por ser um esporte mais midiatizado, torna seus códigos mais acessíveis e mais facilmente compreendidos. Em que pese ser uma representação que permite a identificação de muitos, nas aulas de EF tomadas pela centralidade do esporte, a fronteira estabelecida é da ordem da hierarquia produzida pela performance e pelo valor social de cada prática.

\section{Gueto 3}

Esse é um grupo pequeno, formado por apenas 3 garotas. Exceto pela presença fragmentada de um dos meninos do gueto 2 e por outra garota que pertence ao gueto 4 , as três meninas constituem o único gueto inteiramente composto por meninas negras. Isso é importante de ser destacado, visto que, um dos principais marcadores simbólicos identificados neste grupo é o cabelo. Elas acham bonito o cabelo cacheado e assumem o seu penteado. Se nos dois guetos anteriores a questão da negritude não emerge como fronteira, para elas, essa é "uma forma de valorizar a sua identidade negra”.

Destacamos esse marcador, pois à medida que elas buscam valorizar a cultura negra, negam os demais tipos de penteados e estilos, advindos de grupos que historicamente impóe na sociedade padrôes de corpo e beleza hegemônicos. Quem não segue esses modelos é considerado feio, estranho, errado. No entanto, ao afirmar as suas identidades negras, elas desconsideram os rótulos de beleza e produzem outra significação do que é bonito e feio, certo e errado, de acordo com o apropriado e produzido pelo grupo que representam e se articulam nesse gueto.

Ao adentrarem no espaço da aula, sentavam-se na arquibancada na direção da linha do meio da quadra. Geralmente, levavam um pacote de bolachas e ficavam comendo e conversando. Música, vôlei, comida, meninos, moda e maquiagem compuseram os principais assuntos.

Em algumas aulas, dependendo doânimo, buscavam uma bola de vôlei com a professora e brincavam sem compromisso com a eficiência. Apesar de se identificarem com o vôlei, em nenhum momento das observaçóes entraram na quadra para jogar ou reivindicaram esse direito, reforçando a ausência de qualquer negociação ou de interesse por fazê-la. Isso denota como as fronteiras entre os guetos são expressas a todo instante ao longo das aulas. $\mathrm{O}$ único espaço que sobrava era um pequeno pátio que fica entre a sala de materiais e o fundo da quadra. Uma pequena rede de badminton era adaptada para que pudessem jogar vôlei. Devido ao espaço ser muito restrito, era possível jogar no máximo em duplas.

Mesmo com as restriçóes, quando as meninas escolhiam jogar, passavam bastante tempo ali. As regras do jogo eram adaptadas para as condiçóes: o saque podia ser feito por manchete, cortada e toque; em geral, trocavam apenas um passe antes de jogar bola para o outro lado; o bloqueio era proibido, visto que a rede era muito baixa; aproveitavam-se das rachaduras no cimento para demarcar os limites do espaço de jogo; a contagem das contendas ia até 11 pontos. Quando tinha alguém "de fora", na rodada seguinte, entrava no time que perdeu.

Quando elas jogavam, dois meninos completavam os times. Esses meninos assumiam-se como gays e não pertenciam aos guetos 1 e 2 . Eram motivo de gozaçóes por parte desses grupos, quando em meio ao jogo de vôlei manifestavam-se de forma diferenciada dos modos aprovados pelos meninos. Por outro lado, para as meninas do gueto 3, esse comportamento não era fonte de recusa. Era jocoso e gerava riso. Talvez, como forma de manifestar resistência ao modo de ser rude dos meninos. A manifestação festiva acontecia após momentos de grande esforço nas partidas. Reforça- 
se aqui alguns discursos produzidos ao longo da história que articulam o vôlei e a identidade feminina, marcando os meninos que o praticam como afeminados. O que reforça a identificação desses meninos com esta prática corporal.

Além do vôlei, quando as meninas ficavam sentadas na arquibancada, gostavam de ouvir artistas da Música Popular Brasileira (MPB) tais como Chico Buarque, Milton Nascimento, Gilberto Gil, Cássia Eller, Maria Gadú. Levavam seus celulares com fones de ouvido, que eram compartilhados. Reforçavam discursos que proferem que os colegas de sala não são obrigados a ouvir músicas que não estão com vontade.

Ao mesmo tempo em que ouviam música, algumas vezes, olhavam revistas de cosméticos e produtos de beleza e falavam sobre quais eram melhores para o cabelo e pele. Preferiam os produtos voltados para a mulher negra, visto que os demais, não serviam para o seu tipo de penteado e para a sua cor de pele. Por fim, mesmo com os garotos da turma tentando e impressionar as meninas, elas não demonstravam o mínimo interesse por eles. Além de ficarem bravas por não poderem jogar na quadra, eram constantemente alvo de boladas enquanto jogavam vôlei. Elas também comentavam bastante a respeito dos garotos do bairro, que eram mais velhos.

Percebe-se aqui que, de algum modo, o rola bola contribui para reforçar e, assim, fixar, o vôlei como representação de prática corporal vinculada à identidade do gênero feminino e a da homoafetividade masculina. Mais ainda, por um lado, reforça, nesse gueto, outras representaçōes, que atribuem ao cabelo, a negritude, a feminilidade fronteiras absolutizadas. Por outro, colabora para que nos espaços da aula de EF os estranhos se movimentem em estreita proximidade uns dos outros, reforçando o incômodo da convivência indesejada. Nessa situação, entendemos que o rola bola reproduz, de algum modo, os guetos urbanos analisados por BAUMAN ${ }^{23}$. Para o sociólogo, as formas de segregaçáo desses espaços culminam no que denomina mixofobia urbana: o medo de se misturar com indivíduos estranhos em um espaço comum.

Uma vez que esqueceram ou não se preocuparam em adquirir as habilidades necessárias para uma vida satisfatória em meio à diferença, não é de estranhar que os indivíduos que buscam e praticam a terapia da fuga encarem com horror cada vez maior a perspectiva de se confrontarem cara a cara com estranhos". (p. 94)
Gueto 4

Pode-se dizer que esse é o maior gueto da turma encontrado nas observaçóes. Ele é formado por cerca de 13 garotas. Assim como as meninas do gueto 3, elas se sentam nas arquibancadas, entretanto, além de ficar em uma das pontas, raramente se levantam durante as aulas. Desde o início, aquele é o espaço onde todas as suas atividades são realizadas.

$\mathrm{O}$ ato de permanecerem sentadas afirma a identidade do grupo e indica outra tensão entre os demais grupos. Explicitamente, não se reconhecem na ação dos demais, em meio às práticas corporais ali manifestadas (basquete, futebol e vôlei).

Quando questionadas sobre quais práticas corporais elas gostam de fazer, algumas disseram que gostam de andar, ir na academia e também dançar funk, sertanejo e forró universitário. Isso tornou-se mais evidente ao longo das aulas, pois costumam deixar um celular tocando música, ao lado da roda de conversa. Como o grupo é grande, elas preferem utilizar o celular como se fosse uma caixa de som, para que todas escutem juntas.

No entanto, essas práticas que geram interesse no grupo, não são abordadas nas aulas. A aparente falta de gosto pelos elementos da cultura corporal e interesse pelas aulas de EF pode ser descontruída à medida que compreendemos o contexto e as tensóes entre os guetos ali constituídos. Nas aulas rola bola, as atividades permitidas não faziam parte da cultura corporal dessas meninas. Fato que corrobora as afirmaçóes de Chaim e NeIRA ${ }^{24}$, para quem o currículo da EF distancia-se e, por isso, nega muitas práticas da cultura corporal juvenil. $\mathrm{O}$ que impede qualquer tentativa de aproximaçáo e diálogo entre formas culturais diversas. Decorre disso a escolha por ficarem sentadas.

Em termos étnicos e raciais o grupo é bastante heterogêneo. É composto por meninas brancas, pardas e uma negra. Um marcador simbólico comum encontrado no grupo é o cabelo liso. Apesar da similar preocupação com o cabelo que o gueto 3 tinha, ao contrário da preocupaçáo do estilo de penteado cacheado, nesse, um dos elementos compartilhados pelas garotas era o cabelo liso. Mesmo que para algumas delas, isso só fosse possível a partir de alisamento e tratamento do cabelo.

Destacamos o caso da única menina negra do grupo: Meu cabelo era ruim, duro, por isso eu aliso, não gostava dele
antes, era muito feio! [...] Arrumar ele agora ainda é muito
demorado, mas me sinto melhor assim.

$\mathrm{Na}$ fala desta menina, podemos observar que ela se 
coloca em uma posição diferente das meninas do gueto 3. Para ela, o mesmo tipo de cabelo que as meninas do 3 tentam valorizar, era algo ruim e feio. Expressão que indica a busca da menina pelo paradigma de beleza branca, considerada por ela o padrão ideal. Por não ser o foco desta investigação, não produzimos dados para analisar essa estratégia de identificação por parte da aluna. A destacamos para reforçar outro aspecto do rola bola, que parece declinar não apenas das atividades diretivas que permitem a aprendizagem de conteúdos específicos da Educação Física. Entendemos que os guetos produzidos não permitem deslocar as disposiçóes hegemônicas do poder, tampouco tencionar aspectos que colocam o significante negro essencializado em uma categoria racial biologicamente constituída ${ }^{25}$.

Houve dias em que as meninas do gueto 3, depois de olhar o catálogo de cosméticos e produtos de beleza, deixaram ele com as garotas do 4 para que elas também pudessem olhar e fazer as encomendas. Isso mostra que nessas situaçóes, ambos os grupos compartilhavam do mesmo interesse. No entanto, na procura, visualizamos diferenças entre os guetos, como por exemplo, na escolha de produtos para mulheres com pele clara, de cabelos lisos, enfim, elementos que permitem a construção dos marcadores identitários do grupo.

Encontra-se aqui outro aspecto que caracteriza a cultura juvenil feminina contemporânea negligenciado pela prática do rola bola, qual seja: a construção cultural do corpo feminino por meio de discursos veiculados em revistas e programas especializados para este público. Não sáo poucos, tampouco são recentes os estudos acerca do impacto das mídias diversas nas representaçóes de corpo feminino (e masculino). O rola bola também incorre na ausência de açóes que se preocupam com a vigilância, o controle, a modelagem, a correção dos corpos de meninos e meninas. Se de um lado ele permite que as criticadas açóes disciplinares anatomo-políticas sobre o corpo dos estudantes não ocorram, por outro, ele abre as portas para que pedagogias culturais mais sedutoras e interessantes do que a instituição escolar, transmitam determinados valores e produzam de forma mais eficiente identidades sociais afeitas à promoção e ao consumo da estética da aparência. Mesmo sem intervenção, o rola bola facilita que a educação do corpo seja subjetivada pela lógica mercantil e, com isso, a reificação dos guetos voluntários que colocam o outro bem distante delas.

Com a música tocando, elas conversavam bastante. Falam "de tudo um pouco", como por exemplo: filmes, séries, novela, música, bebida, drogas (maconha e cocaína) e garotos. Porém guardam distanciamento, por medo de que os segredos se espalhassem. "Estamos fazendo fofoca dos meninos, é melhor você não escutar isso!”. Fronteiras que não permitiram ser borradas.

A relação das meninas desse gueto com os meninos da sala foi algo que nos chamou atenção. Nos momentos de "fofoca" os meninos que iam jogar vôlei com as garotas do gueto 3, se aproximavam. Parece que eles gostavam de compartilhar dos assuntos ali discutidos. Além destes, elas também gostavam bastante de conversar com os meninos do gueto 1 , principalmente nos momentos em que eles ficavam jogando futebol nas laterais da quadra, esperando o basquete terminar. Assim, encontramos certa convergência entre a intenção do gueto 1 , no sentido de impressionar as garotas. Mas também da parte delas em aceitar as conversas e, em vários momentos, formas diversas de afetos. Entre os guetos, como eles diziam, isso sempre acontecia em tom de piada e "xaveco". No entanto, encontramos para essas mesmas situaçóes diferentes efeitos e reaçóes entre os demais guetos. Para os meninos do gueto 2 , era legal olhar e quando acontecia algo considerado mais "pesado", eles riam. Porém, em nenhum momento eles encontravam abertura para brincar da mesma forma com as garotas. Alguns deles conseguiam conversar com as meninas do gueto 3 , que se comportavam de forma diferente do gueto 4 , não dando tanta liberdade para os meninos.

De todo modo, o que se percebe é que, o rola bola não produz um diálogo entre os sujeitos enquanto representantes de práticas corporais específicas, muito menos possibilidades para melhor compreendê-las. $\mathrm{O}$ contato seja entre os grupos identitários seja entre as diferenças ora produzidas fica reduzido para alguns momentos, apenas no campo das relaçóes amorosas.

\section{Gueto 5}

O último gueto encontrado ao longo das observações era composto por apenas 2 alunos, um garoto e uma garota. Em todas as aulas observadas, eles sempre se mantiveram distantes de todos os outros grupos. Não estabeleciam relação de diálogo em nenhum momento. Ficavam sentados na arquibancada, bem próximos da entrada da quadra.

Apesar de estarem cursando o $2^{\circ}$ ano assim como os demais, eram alunos mais velhos e repetentes. No caso em questão, esse talvez seja o principal marcador simbólico desse grupo, visto que, por serem mais velhos suas açóes, conversas, valores, eram diferentes dos outros guetos.

Em uma das aulas observadas, os garotos do gueto 1 estavam jogando futebol na quadra e em determinada jogada, um deles sofreu um drible por entre as pernas, 
o que eles chamam de "caneta". Há uma regra na brincadeira deles, em que toda vez que alguém sofre uma "caneta", a pessoa deverá levar chutes até que a mesma corra e encoste-se a uma das colunas, que estruturam o telhado da quadra. No dia, quando isso aconteceu, o garoto correu na direçáo da menina do gueto 5 , que estava sentada perto de uma das colunas. Ela se assustou com os chutes e a gritaria dos garotos e se protegeu colocando os braços na frente do rosto e encolhendo as pernas. Afinal, como membro de fora não compreendia esses códigos. Assim que os garotos foram embora, ela comentou zangada: "Nossa, como o pessoal dessa sala é idiota, infantil! Odeio isso, por que não conseguem agir direito, com calma?”.

Essa fala define a idade, a geração como marcador identitário. No enunciado, ela se coloca na posição de uma pessoa madura, calma, que náo participa desse tipo de brincadeira. Ao mesmo tempo, ela coloca não só os garotos do gueto 1, mas todo o restante da sala, como infantis que não conseguem conviver sem serem "idiotas". O rola bola contribui para marcar concepções do ser infantil.

A partir desse dia, eles começaram a contar um pouco sobre as suas trajetórias escolares. $\mathrm{O}$ garoto tinha duas repetências e a garota uma, isso de certa forma criava um vínculo entre os dois. Nas narrativas, destacamos que, até certo momento da vida escolar, eles tinham expectativas de conseguir cursar o Ensino Médio em uma escola técnica, preparatória para o vestibular.

A garota por exemplo, quando estava no $9^{\circ}$ ano, disse ter se preparado muito para o vestibulinho de uma escola importante da cidade. Com uma nota baixa, não conseguiu entrar e teve que cursar $\mathrm{o} 1^{\circ}$ ano $\mathrm{em}$ uma escola com condiçóes muito precárias. Frustrada com a situação, ela escolheu repetir o ano, para poder prestar novamente o teste. Novamente com o fracasso, ela decide mudar para a escola onde fizemos a pesquisa e desde então, assim como o garoto do seu gueto, suas expectativas em relação à escola se resumiram a estudar para passar de ano e sair o mais rápido possível da escola.

Nenhum dos outros guetos comentaram algo relacionado à frustração com a escola. Alguns também afirmam não gostar de estudar, mas, sempre que possível, encontravam alguém que havia feito as lições de casa e copiavam, demonstrando o limite entre o comprometimento com o que era exigido e estratégias para subsistir às demandas escolares. No gueto 5 , por sua vez, seus membros não se preocupavam com isso, falavam que "não perdiam o tempo" com lições ou preocupações do tipo, apenas estudavam e tentavam tirar nota nas provas.
O garoto conta com orgulho, que em uma das aulas de Geografia, após ter levado uma chamada de atenção do professor por não ter feito lição de casa, ele decidiu colocar fogo no lixo da sala. Para ele, simbolicamente foi um ato de resistência ao modelo escolar que tenta impor ao aluno diversos fazeres, que não tem sentido para a sua vida (quando falava isso, ele apontava para a aula de Educação Física, incluindo-a no comentário).

$\mathrm{Na}$ perspectiva dos demais guetos, eles ficaram inconformados com a ação do garoto. As meninas do gueto 4 usaram significantes como "satânico" e "do capeta" para significar o que ele fez. Já os garotos do gueto 2 , náo entenderam o motivo de tanta revolta com a escola e também se mostraram contrários a atitude.

Apesar do descontentamento com a escola, eles estavam sempre com livros na mão. Gostavam de ler literatura brasileira, livros de ficção científica e após o termino do colégio, tinham a intenção de continuar estudando no nível superior. $\mathrm{O}$ garoto mesmo com vontade, ainda não sabe muito o que fazer. Já a garota, quer fazer Arquitetura e Urbanismo.

Para suprir os problemas de conteúdo no Ensino Médio, eles disseram que fariam cursinhos para tentar entrar em Universidades Públicas, mas, caso não conseguissem, tentariam alguma instituição particular para não perder mais tempo. Novamente, esse tipo de pensamento, sobre trabalho e curso profissional, comum em grupos de jovens mais velhos, em nenhum momento apareceu nos outros guetos, mostrando a faixa etária como marcador de identidade, mas também na própria visão de futuro e mundo.

Por fim, quando perguntamos os motivos deles não pedirem nenhum material, ou tentarem jogar algo, dois argumentos diferentes foram dados. O primeiro, do garoto, foi em relação à falta de vontade de se relacionar com os demais alunos. A garota por sua vez, em sua justificativa, resume algo já destacado em nossas interpretaçóes. Ela faz parte da torcida organizada de um time tradicional de futebol e frequenta o estádio junto com seu padrasto. Gosta de assistir aos jogos e falar sobre futebol e também jogar um pouco.

No entanto, apesar desse ser o esporte que estava presente em todas as aulas observadas, vários fatores, na sua visão, impediam que ela o praticasse. Primeiro, por ela não gostar dos meninos do gueto 1 e de suas brincadeiras com as meninas do gueto 4. Segundo, por mais que ela soubesse falar e jogar futebol, o fato de ser mulher, repetente e mais velha gerava muita vergonha, visto que o espaço e a prática dentro da aula eram marcados majoritariamente pelos meninos e com faixa etária adequada ao ano vigente.

Pode-se ver que esse gueto expressa e por isso reforça 
discursos por meio das estatísticas que indicam a inoperância da escola pública. De algum modo, para os demais integrantes dos outros guetos, os membros do gueto 5 são a materialidade da ameaça que representa estudar nessa instituição. Não à toa, não há espaço para borrar fronteiras. Como se vê, o fracasso escolar é a condiçâo para o fechamento mais hermético dos guetos culturais.

\section{Acabamento provisório}

A partir da investigação apresentada sobre os efeitos da prática pedagógica rola bola na produção cultural da identidade do componente Educação Física e na dos alunos de uma turma, mostramos a complexidade da dinâmica das relaçóes sociais. Questionamos, sobretudo, os discursos que dizem que "nada acontece" nesse tipo de aula, além dos enunciados que afirmam seu caráter neutro e de mero momento de diversão.

Ao longo da interpretação, chamamos atenção para como os guetos constituem e expressam sua identidade na relação com os outros e marcam negativamente as diferenças. Os 5 grupos apresentados criaram nessas relaçóes vários marcadores simbólicos para comunicar seu posicionamento, por meio de discursos, gestos e artefatos utilizados pelos sujeitos.

Todo esse conjunto de marcadores são significados de diferentes formas pelos grupos e nesse processo sempre tenso e dinâmico, as fronteiras dos guetos são criadas, afirmadas e remodeladas de acordo com as situaçôes. Assim, apesar de apresentar os guetos na narrativa de forma separada, enfatizamos como na vida social e dialógica da aula rola bola eles tornam-se dependentes uns dos outros. Em vários eventos, eles se misturam e se hibridizam ou se repelem e se afastam. Essa constatação tem a ver com o imbricamento eu-outro na produção das identidades enquanto norma, e diferenças, marcadas como indesejáveis, ameaças, assim como, das relações de poder produzidas nesse movimento por meio das habilidades motoras e cognitivas, da faixa etária, da normatividade afetiva ou das questóes de gênero e raça.

Por fim, ao longo das observaçóes, percebemos que apesar das aulas rola bola, permitirem aleatoriamente nas fronteiras contatos entre os guetos, essa dinâmica fica restrita aos modos de relação aceitos e permitidos pelas lógicas de poder ali produzidas. Nesse sentido, no ato de rolar bola a professora contribuiu com a legitimação do exercício de poder de determinados grupos para ocupar os espaços da quadra, escolher as práticas corporais que são realizadas e também, ao mesmo tempo, com o processo de marginalização de outros grupos, que não correspondem ao valorizado pela cultura esportiva e pelo grupo ali legitimado.

O rola bola, enquanto dispositivo do currículo, potencializa as estratégias de identificação para que tenham maior força divisora, do que solidária. Independentemente de qualquer análise referente à negligência no tocante aos aspectos didáticometodológicos que o rola bola implica, cabe destacar o seu caráter constitutivo, produtivo e regulador da cultura escolar e, quiçá, reprodutor dos mecanismos de exclusão da cultura mais ampla. Ao se abster de planejar a aula e deixar a bola rolar, a docente contribui para consolidar formas hegemônicas e universais de ser, que afirmam as identidades válidas e tornam a diferença em incômodo que tem que ficar à margem, negando-a enquanto potência, enquanto multiplicidade. Há mais! $\mathrm{O}$ rola bola favorece a circulação de artefatos e discursos midiáticos, impregnados de elementos instituintes daquilo que funciona como "verdade" das coisas do mundo e dos sujeitos. Ao facilitar a produção de guetos identitários, produz em seu interior e nas suas bordas uma economia política da verdade que coloca em jogo o poder de quem narra como o outro é e permite formas de circulação.

Se, dê um lado o rola bola não colabora para processos de homogeneização cultural, para o qual a escola foi pensada e que tem na Educação Física um dispositivo que atua por meios de seus currículos tradicionais ou críticos $^{\mathrm{d}}$ a fim de alcançar suas metas, por outro, o rola bola favorece fechamentos de identidades culturais, o fortalecimento da relação nós versus eles, a produção da diferença enquanto estranho, incentivando formas locais de fundamentalismos, de guetos voluntários. $\mathrm{O}$ que se vê é a cultura escolar reificar a natureza excludente dos condomínios fechados, shopping centers, parques engradados e, com isso, produzir particularidades. $\mathrm{O}$ rola bola facilita a naturalização e a estabilização de identidades em grupos, que convivem por imposição, por conta de um espaço-tempo delimitado. As diferenciaçóes que produz incluem alguns e excluem outros, algumas vezes de forma mais sentida e reproduz formas arbitrárias de modelos identitários produzidos nas mídias que os alunos acessam. De forma assertiva, o rola bola define agrupamentos e reforça a dificuldade dos sujeitos da educação em lidar com o caráter emergente, fragmentado, contraditório e imanente que caracterizam a existência dos humanos. 
Com essa forma de atuação perde-se a oportunidade de problematizar como as coisas se tornam o que são, seja o Outro ou a si mesmo. Perde-se a oportunidade de questionara produção dos discursos que afirmam ou negam as práticas da cultura corporal e seus representantes, bem como perde-se a oportunidade de não os tratar como totalidade. Enfim, perde-se a oportunidade de construir de maneira sistematizada e intencional, aulas nas quais a circulação e negociação de sentidos ocorra de forma dinamizada e confrontada em favor de uma sociedade mais justa, democrática e responsável para com a afirmação das diferenças.

\title{
Notas
}

a. Gueto era o nome dos bairros em que outrora os Judeus eram obrigados a residir nas cidades europeias ao longo da Segunda Guerra Mundial. Local onde uma minoria é separada do resto da sociedade. Se outrora o gueto era um local de marginalização compulsória, para BAUMAN ${ }^{23}$, nas sociedades contemporâneas os guetos se tornam uma opção desejável e segura para os que não querem correr riscos de entrar em contato com os outros indesejáveis. Trata-se de uma forma social de segregação espacial que não impede a saída de seus membros, mas implica uma negação da liberdade por não permitir a entrada dos estranhos.

b. Ao invés de ser concursada e ser efetiva, professores desta categoria são contratados todo ano, para substituir turmas que os professores faltam ou que estão vagas devido aos docentes terem assumido cargos administrativos nas instituiçóes da rede.

c. Não cabe aqui a análise do programa curricular do Estado de São Paulo. No entanto, corroboramos as análises críticas já realizadas que enfatizam que se trata de uma proposta que hibridiza tendências pedagógicas antagônicas (crítica-emancipatória e saúde renovada).

d. Neira e Nunes² ressaltam que tanto os currículos críticos (superador e emancipatório), como os tradicionais da Educação Física (os que perseguem a melhoria da aptidão física, a adoção de um estilo de vida fisicamente ativo, o ensino esportivo, o desenvolvimento motor e a otimização das funçóes psicomotoras), enquanto produtos do pensamento moderno, se alinham na finalidade de homogeneização cultural, tomando como premissa a noção de um sujeito universal, racional e com identidade estável.

\begin{abstract}
Rola bola: a dispositif that produces cultural ghettos.

Among the several pedagogical practices produced at Physical Education curriculum, we investigated in this research the popularly called "rola bola". We aim to infer its effects on a 2nd grade High School class from a school in the state of São Paulo. Through an ethnography, we made observations recorded in diaries for the production of data. For the interpretation of the results, we take the notions of identity and difference produced in the field of Cultural Studies in its poststructuralist dimension. As effect, we noticed the presence of cultural ghettos instituted in the course of the classes, in which symbolic frontiers that delimit forms of belonging of the subjects are evidenced, as well as the conditions of possibilities negotiation promoted by the relationships and social practices that emanate within the classes.
\end{abstract}

KeYwords: Physical Education; High School; Curriculum; Identity; Diferrence. 


\section{Referências}

1. Bracht V. Educação Física no $1^{\circ}$ grau: conhecimento e especificidade. Rev Paul Educ Fís.1996;2:23-28.

2. Neira MG, Nunes MLF. Pedagogia da Cultura Corporal: críticas e alternativas. São Paulo: Phorte, 2006.

3. Nunes MLF, Rubio K. O(s) currículo(s) da Educação Física e a constituição da identidade de seus sujeitos. Currículo Front. 2008;8:55-77.

4. Machado TS, Bracht V, Faria BA, Moraes CEA, Almeida UR, Almeida FQ. As práticas de desinvestimento pedagógico na educação física escolar. Movimento (UFRGS. Impresso). 2010;16:129-147.

5. Gonzalez FJ, Fensterseifer PE, Glitz AP, Ristow RW. O abandono do trabalho docente em aulas de educação física: a invisibilidade do conhecimento disciplinar. Educ Física Cienc. 2013;15:1-12.

6. Foucault M. Microfísica do poder. Rio de Janeiro: Graal, 1992.

7. Maia TVA. Pesquisa etnográfica no campo do currículo em uma perspectiva pós-estruturalista: um diálogo possível? Espaço Curr. 2013;6:171-9.

8. Silva TT, Hall S, Wooward K. Identidade e diferença: a perspectiva dos estudos culturais dos estudos culturais. Petrópolis, Rio de Janeiro: Vozes, 2000.

9. Bakhtin M. Os gêneros do discurso. São Paulo: Editora 34, 2016.

10. Volóchinov V (Círculo de Bakhtin). Marxismo e filosofia da linguagem: problemas fundamentais do método sociológico na ciência da linguagem. São Paulo: Editora 34; 2017.

11. Hall S. Quem precisa de identidade? In: Silva TT (organizador) Identidade e diferença: As perspectivas dos Estudos Culturais. Petrópolis: Vozes; 2000, p.103-133.

12. Hall S. The work of representation. In: Hall S, organuizador. Representation: cultural representation and cultural signifying practices. London/Thousand Oaks/New Delhi: Sage/Open University, 1997,

13. Wooward K. Identidade e diferença: uma introdução teórica e conceitual. In: Silva TT. Identidade e diferença: a perspectiva dos Estudos Culturais. Petropólis: Vozes, 2000.

14. Costa MV, Wortmann ML, Bonin IT. Contribuiçóes dos Estudos Culturais às pesquisas sobre currículo: uma revisão. Currículo Front. 2016;16:509-541.

15. Nunes MLF. Educação Física e esporte escolar: poder, identidade e diferença [dissertação]. São Paulo: USP, Faculdade de Educaçáo; 2006.

16. Mclaren P. Multiculturalismo Revolucionário: pedagogia do dissenso para novo milênio. Porto Alegre: Artmed, 2000 .

17. Giroux H. Atos impuros. Porto Alegre: Artmed, 2003.

18. Popkewitz TS. História do currículo: regulaçáo social e poder. In: Silva TT. O sujeito da educação: estudos foucaultianos. Petrópolis: Vozes, 1995, p. 7-72.

19. Vago TM. Das escrituras à escola pública: a educação física nas séries iniciais do $1^{\circ}$ grau [dissertação]. Belo Horizonte: UFMG, Faculdade de Educação; 1993.

20. Altman H. Marias (e) homens nas quadras: sobre a ocupação do espaço físico escolar. Educ Realidade. 1999;24: 157-74.

21. Wenetz I. Gênero e sexualidade nas brincadeiras de recreio [dissertação]. Porto Alegre: UFRGS, Faculdade de Educação Física; 2005.

22. Canclini NG. Consumidores e cidadãos: conflitos multiculturais da globalização. Rio de Janeiro: Ed. UFRJ, 2006. 23. Bauman Z. Tempos Líquidos. Rio de Janeiro: Jorge Zahar editora, 2007.

24. Chaim CI, Neira MG. Cultura Juvenil e Educação Física. In: Neira MG, organizador. Educação Física Cultural. Coleção: reflexão e a prática no Ensino Médio. São Paulo: Blucher, 2016.

25. Hall S. Que negro é esse na cultura negra? In: Da diáspora: identidades e mediaçóes culturais. Belo Horizonte: Editora da UFMG; 2003, p. 335-349. 
Rola bola: dispositivo que produz guetos culturais

ENDEREÇO Universidade Estadual de Campinas Av. Érico Veríssimo, 701

Cidade Universitária Zeferino Vaz

13083-851 - Campinas - SP - Brasil Submetido: $14 / 08 / 2017$

Revisado: 19/03/2018

E-mail: gabriel.spolaor@hotmail.com 